\title{
INFLUENCE OF 5-HT1A AGONIST ON THE FEEDING BEHAVIOR OF Coturnix japonica (GALLIFORMES: AVES)
}

\author{
REIS, L. C. ${ }^{1}$ and MARINHO, V. R. ${ }^{2}$ \\ ${ }^{1}$ Departamento de Ciências Fisiológicas, Instituto de Biologia, UFRuralRJ, CEP 23890-000, Seropédica, RJ, Brazil \\ ${ }^{2}$ Monografista de Ciências Biológicas, Biomedicina da UNIRIO, CEP 22290-040, Rio de Janeiro, RJ, Brazil \\ Correspondence to: Luís Carlos Reis, Departamento de Ciências Fisiológicas, Instituto de Biologia, \\ UFRuralRJ, CEP 23890-000, BR 465, Km 07, Seropédica, RJ, Brazil, e-mail: lcreis@ufrrj.br \\ Received November 19, 2003 - Accepted February 16, 2004 - Distributed November 30, 2005
}

(With 4 figures)

\begin{abstract}
In this study, we investigate the effect of serotonin receptor 5-HT1A stimulation on the feeding behavior of quails (Coturnix japonica). The administration of 5-HT1A agonist, 8-OH-DPAT (0.05 to $5.0 \mathrm{mg} / \mathrm{Kg}$ ) dose-dependently inhibited the food intake in normally fed quails. Greater inhibition was attained with $5.0 \mathrm{mg} / \mathrm{kg}(0.93 \pm 0.21 \mathrm{~g} v s .5 .83 \pm 0.25 \mathrm{~g}, \mathrm{P}<0.05,2 \mathrm{~h}$ after food offer $)$. A comparable response was obtained from previously fasted quails. At end of $2 \mathrm{~h}$, a higher dose of 8-OH-DPAT induced more intense hypophagy $(1.59 \pm 0.41 \mathrm{~g}$ vs. $6.85 \pm 1.04 \mathrm{~g}, \mathrm{P}<0.0001)$. Previous treatment with the antagonist 5-HT1A/ $\beta$-adrenergic, propranolol, failed to block the inhibitory action of 8-OH-DPAT, but instead, intensified it (controls, $5.22 \pm 1.09 \mathrm{~g}$; 8-OH-DPAT, $1.41 \pm 0.19 \mathrm{~g}$; propranolol + 8-OH-DPAT, $0.44 \pm 0.25 \mathrm{~g}$, $\mathrm{P}<0.01$, for all comparisons). The administration of an isolated higher dose of propranolol induced a hypophagic action (controls, $4.5 \pm 0.8 \mathrm{~g} v s$. propranolol, $2.0 \pm 0.2 \mathrm{~g}, \mathrm{P}<0.01$ ). Current outcomes suggest a possible role of 5-HT1A receptor on the feeding behavior of quails, as opposed to mammals. On the other hand, the intensified hypophagy induced by previous administration of propranolol raises the hypothesis of a $\beta$-adrenergic excitatory mechanism that controls the feeding behavior of quails.
\end{abstract}

Keywords: feeding behavior, 5-HT1A receptor, serotonergic system, quails, Coturnix japonica.

\section{RESUMO}

\section{Influência de agonista 5-HT1A sobre o comportamento alimentar em Coturnix japonica (Galliformes: Aves)}

Investigamos no presente trabalho o efeito da estimulação de receptor serotonérgico 5-HT1A no comportamento alimentar de codornas (Coturnix japonica). A administração do agonista 5-HT1A, 8-OH-DPAT $(0,05$ a $5,0 \mathrm{mg} / \mathrm{kg})$, inibiu de modo dose-dependente a ingestão de alimento em codornas normoalimentadas. A inibição mais intensa foi obtida com a dose de $5,0 \mathrm{mg} / \mathrm{kg}(0,93 \pm 0,21 \mathrm{~g} v \mathrm{~s}$. $5,83 \pm 0,25 \mathrm{~g}, \mathrm{P}<0,05,2 \mathrm{~h}$ após a oferta de alimento). Resposta comparável foi alcançada nas aves previamente submetidas ao jejum alimentar. Ao final de $2 \mathrm{~h}$, a dose maior de 8-OH-DPAT induziu a uma intensa resposta hipofágica $(1,59 \pm 0,41 \mathrm{~g} v s .6,85 \pm 1,04 \mathrm{~g}, \mathrm{P}<0,0001)$. O tratamento prévio com o antagonista 5-HT1A/ $\beta$-adrenérgico, propranolol, não bloqueou a ação inibidora do 8-OH-DPAT na ingestão alimentar, ao contrário, intensificou-a (controles, 5,22 \pm 1,09 g; 8-OH-DPAT, 1,41 \pm 0,19 g; propranolol +8 -OH-DPAT, $0,44 \pm 0,25 \mathrm{~g}, \mathrm{P}<0,01$, para todas as comparações). A administração isolada de propranolol evidenciou uma ação hipofágica com a dose maior (controles, 4,5 $\pm 0,8 \mathrm{~g} v s$. propranolol, $2,0 \pm 0,2 \mathrm{~g}, \mathrm{P}<0,01)$. Os resultados obtidos evidenciaram um possível papel dos receptores 5-HT1A na modulação do comportamento alimentar em codornas de natureza oposta ao referido para mamíferos. Por outro lado, a potencialização da hipofagia pela prévia administração de propranolol suscita a hipótese de um mecanismo $\beta$-adrenérgico excitatório no controle do comportamento alimentar em codornas.

Palavras-chave: comportamento alimentar, receptor 5-HT1A, sistema serotonérgico, codornas, Coturnix japonica. 


\section{INTRODUCTION}

The midbrain serotonergic system consists of a midline group of serotonin neurons which projects toward forebrain structures (Azmitia \& Segal, 1978). Serotonergic neurons innervate hypothalamic areas involved with feeding and other homeostatic and behavioral functions. Futhermore, the serotonergic system plays a critical role in the collaborative organization of the forebrain (Azmitia, 1987). Studies involving mammals, particularly mice and rats, implicated the brain serotonergic system in the control of satiety and appetite (Blundell, 1984; 1991; Blundell \& Hill, 1987). In this context, early observations reported the relevance of an increased brain availability of tryptophan (initial precursor of serotonin synthesis) and a resulting increase in serotonin brain content (Fernstrom \& Wurtman, 1971a, 1971b; Fernstrom, 1983).

Reduced food intake response is associated with an increase of serotonin release in the lateral hypothalamic area, a region involved in feeding coordination (Shimizu et al., 1992). On the other hand, a decrease in the firing rate of the raphe serotonergic neurons elicits decreased ascending serotonergic transmission and resulting hyperphagy. These observations were made after the microinjection of 5-HT1A agonist, which acts on somatodendritic autoreceptors in the midbrain raphe, whose stimulation induces a decrease in serotonin release at forebrain postsynaptic sites (Dourish et al., 1986; Hutson et al., 1986; 1988; Bendotti \& Samanin, 1986, 1987; Aghajanian et al., 1990; Curzon, 1990, 1991; Voigt et al., 2000).

This response is evidenced in normally fed rats, while the opposite response was elicited from fasted rats. Blockade of 5-HT1A receptors by $5-\mathrm{HT} 1 \mathrm{~A} / \beta$-adrenergic antagonists, pindolol or propranolol administration suppressed the physiologicalinhibition, with subsequentrestoration of serotonergic transmission (Aghajanian et al., 1990; Curzon, 1990).

There is a paucity of reports on investigations into the physiological correlation between the serotonergic system and feeding behavior control in birds (Rosebrough, 1996; Saadoun \& Cabrera, 2002; Reis et al., 2005). The topographic and functional organization of the serotonergic system in birds maintained homologies with reptiles and mammals (Dubé \& Parent, 1981; Parent, 1981;
Parent et al., 1981; Duchala et al., 1984; Sako et al., 1986; Cozzi et al., 1991; Challet et al., 1996; Gruss \& Braun, 1997). However, studies about the participation of serotonin receptors in the feeding behavior of quails (Coturnix japonica) are absent from the literature, although receptors for serotonin have been identified in bird brains (Gleeson et al., 1992; Saadoun \& Cabrera, 2002).

Observations in our laboratory have evidenced the participation of 5-HT2C receptors in the modulation of the feeding behavior of quails, similar to what has been reported for murines (CedrazMercez et al., 2003, submitted). However, only one paper shows the involvement of 5-HT1A in the food intake in birds (Saadoun \& Cabrera, 2002). These authors demonstrated inhibition of food intake in fasted broiler chickens treated with 5-HT1A agonist. Meanwhile, to date we are unaware of the existence of specific data on the role of 5-HT1A receptors in the feeding behavior of quails.

This study involved an evaluation of the possible phylogenetic correspondence of the inducing mechanisms of hyperphagy by administration of 5-HT1A agonist, 8-hydroxydi-propil-amino-tetraline (8-OH-DPAT) described for mammals in comparison with quails. In fact, our results should lead to speculations about the involvement of 5-HT1A receptors in the control of ascending serotonergic activity.

In addition, we examine the influence of previous administration of $5-\mathrm{HT} 1 \mathrm{~A} / \beta$-adrenergic antagonist, propranolol, on the food intake of quails treated with 5-HT1A agonist.

\section{MATERIAL AND METHODS}

\section{Animals and handling}

After their adaptation to laboratory conditions, male adult quails weighing 120-150 g were housed in individual cages, fed ad libitum with water and special food (20\% raw protein, Purina Inc.) and kept at room temperature $\left(25-30^{\circ} \mathrm{C}\right)$ under controlled photoperiods ( $12 \mathrm{~h}$ light $/ 12 \mathrm{~h}$ dark: lights on at 7 a.m. and off at 7 p.m.).

\section{Procedures}

Experiments were carried out on birds fed normally or fasted for $6 \mathrm{~h}$ prior to the experiments (7:00 to 13:00 h). Food intake was measured in a device built specifically to prevent feed wastage. 
The amount of food ingested was determined with an electronic precision scale. Each bird cage was isolated from the others to avoid visual and physical contact among the birds. All injections of 8-OH-DPAT (Research Biochemical Inc., USA) were made subcutaneously (sc) in the dorsal region, while propranolol (Sigma-Aldrich, USA) injections were applied in the visceral cavity (vc).

\section{Evaluation of the involvement of 5-HT1A receptors in the control of food intake by normally fed quails}

To evaluate the involvement of 5-HT1A receptors in the food intake, normally fed quails were treated with 8-OH-DPAT in doses of zero (control group injected with pure isotonic saline, $(\mathrm{N}=12) ; 0.05(\mathrm{~N}=12) ; 0.1(\mathrm{~N}=14) ; 1.0(\mathrm{~N}=12)$ and $5.0(\mathrm{~N}=10) \mathrm{mg} / \mathrm{Kg}, \mathrm{sc}, 15 \mathrm{~min}$ before food was offered.

\section{Evaluation of the involvement of 5-HT1A} receptors in the control of food intake by fasted quails

An additional group of $6 \mathrm{~h}$ fasted quails were injected with 8-OH-DPAT in doses of zero (control group injected with isotonic saline, $\mathrm{N}=12) ; 1.0$ $(\mathrm{N}=12)$ and $5.0(\mathrm{~N}=10) \mathrm{mg} / \mathrm{Kg}, 15 \mathrm{~min}$ before food was offered.

\section{Evaluation of previous administration of 5-HT1A//-adrenergic, propranolol, on the food intake if normally fed quails treated with 8-OH-DPAT}

In this condition, normally fed quails were previously treated with $5-\mathrm{HT} 1 \mathrm{~A} / \beta$-adrenergic antagonist, propranolol $(5.0 \mathrm{mg} / \mathrm{Kg}, 30 \mathrm{~min}$ before food was offered) associated with an 8-OH-DPAT injection $(5.0 \mathrm{mg} / \mathrm{kg}, 15 \mathrm{~min}$ before being fed) $(\mathrm{N}=10)$. The control group was treated with saline, $0.1 \mathrm{~mL} / 100 \mathrm{~g}, \mathrm{vc}$ and $\mathrm{sc}$, respectively $(\mathrm{N}=12)$.

\section{Evaluation of 5-HT1A/ $\beta$-adrenergic, propranolol administration in the food intake of normally fed quails}

In this condition, 5-HT1A/ $\beta$-adrenergic antagonist, propranolol was injected in doses of zero (control group injected with isotonic saline, $(\mathrm{N}=12) ; 1.0(\mathrm{~N}=12)$ and $5.0(\mathrm{~N}=10) \mathrm{mg} / \mathrm{Kg}$, $30 \mathrm{~min}$ before food was presented.

\section{RESULTS}

Administration of 5-HT1A, 8-OH-DPAT agonist dose-dependently inhibited the food intake of normally fed quails (Fig. 1). Inhibition was more intense with the higher dose $(0.93 \pm 0.21 \mathrm{~g} v s$. $5.83 \pm 0.25 \mathrm{~g}, \mathrm{P}<0.05,2 \mathrm{~h}$ after food was offered). A comparable response was elicited from fasted quails (Fig. 2). By end of $2 \mathrm{~h}$, the higher dose

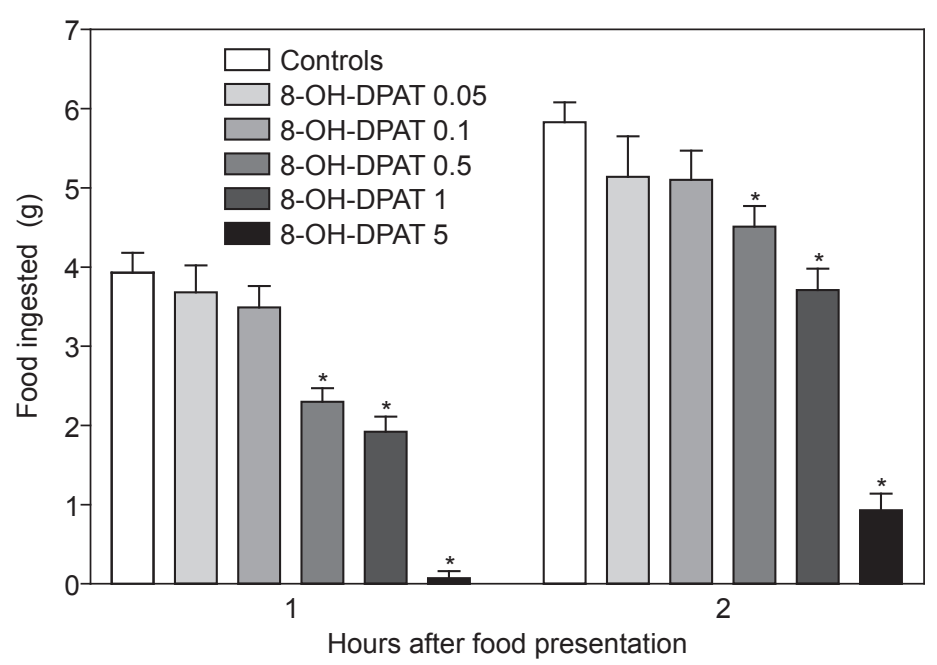

Fig. 1 - Effect of serotonin 5-HT1A agonist 8-OH-DPAT $(0.05,0.1,0.5,1.0$ and $5.0 \mathrm{mg} / \mathrm{Kg}$, sc) on the food intake in normally-fed quails. Data are reported as mean \pm SEM. $* \mathrm{P}<0.0001$ compared to controls. 


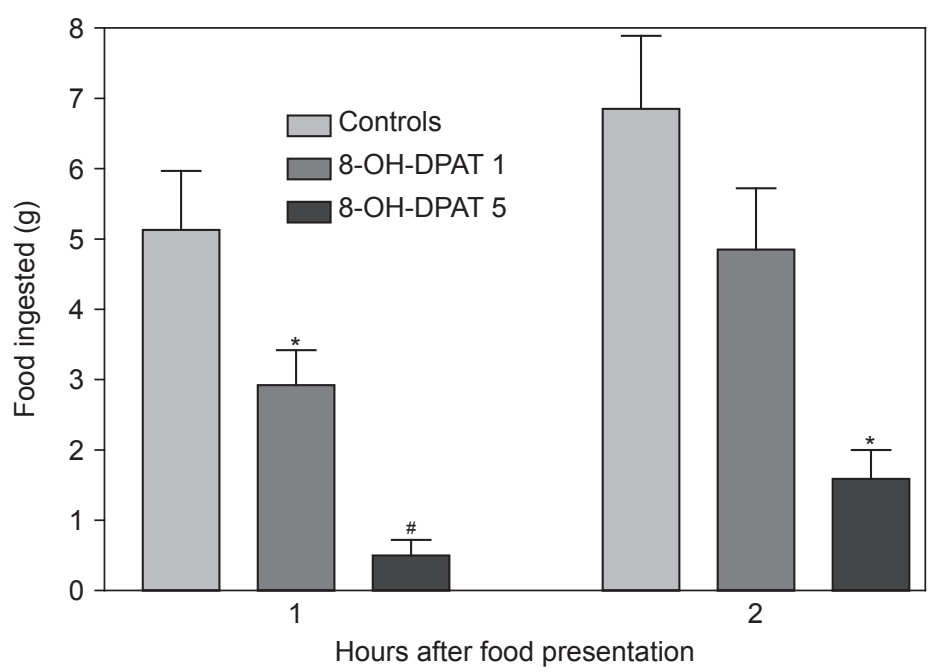

Fig. 2 - Effect of serotonin 5-HT1A agonist 8-OH-DPAT (1.0 and $5.0 \mathrm{mg} / \mathrm{Kg}$, sc) on the food intake of fasted quails. Data are reported as mean \pm SEM. $* \mathrm{P}<0.0001$ and ${ }^{\#} \mathrm{P}<0.01$ compared to controls.

of 8-OH-DPAT had induced intense hypophagy $(1.59 \pm 0.41 \mathrm{~g} v s .6 .85 \pm 1.04 \mathrm{~g}, \mathrm{P}<0.0001)$.

Instead of blocking the inhibitory action induced by $8-\mathrm{OH}-\mathrm{DPAT}$ on the food intake, the previous treatment with $5-\mathrm{HT} 1 \mathrm{~A} / \beta$-adrenergic antagonist, propranolol intensified it (controls, $5.22 \pm 1.09 \mathrm{~g} ; 8$-OH-DPAT, $1.41 \pm 0.19 \mathrm{~g}$; propranolol +8 -OH-DPAT, $0.44 \pm 0.25 \mathrm{~g}$, $\mathrm{P}<0.01$, for all comparisons) (Fig. 3).

The isolated administration of a higher dose of propranolol produced a hypophagic effect (controls, $4.5 \pm 0.8 \mathrm{~g}$ vs. propranolol, $2.0 \pm 0.2 \mathrm{~g}$, $\mathrm{P}<0.01$ ) (Fig. 4).

\section{DISCUSSION}

Our results indicated that the 5-HT1A agonist, 8-OH-DPAT inhibited the food intake of both normally fed and fasted quails. This finding is contrary to what has been reported for mammals, in which the agonist 8-OH-DPAT induces hyperphagy (Dourish et al., 1986). Agreement can be found in the literature about the hypothesis whereby the stimulation of 5-HT1A somatodendritic autoreceptors in the raphe induces reduction in serotonin turnover on the forebrain loci (Dourish et al., 1986; Hutson et al., 1986, 1988; Bendotti \& Samanin, 1986, 1987; Aghajanian et al., 1990; Curzon, 1990, 1991; Voigt et al., 2000). Thus, a terminal button of the serotonin neuron feeds backs toward the perikaryon, where it ends a loop of autoinhibition. This postulation is based on data indicating that the excitation of somatodendritic autoreceptors induces activation of the Gi subunit of $G$ protein, with a subsequent decrease in cAMP generation and a resulting decrease in the firing rate of serotonergic neurons (Aghajanian et al., 1990). In their microdialysis study, Voigt et al. (2000) found that the intraperitoneal injection of 8-OH-DPAT induced a significant decrease of serotonin release in the lateral hypothalamus and an increase in food intake by freely feeding rats. In contrast, the same dose of 8-OH-DPAT had no effect on serotonin release in the lateral hypothalamus and decrease in food intake by food-deprived rats. Voigt et al.'s data (2000) suggest that distinct feeding-related behavioral states influence serotonin release in the lateral hypothalamus.

Our results are contradictory to the above mentioned statements. Our hypophagic results for both fasted and normally fed quails are in partial agreement with the findings of Voigt et al. (2000) and Saadoun \& Cabrera (2002). These authors reported the inhibition of food intake in both fasted rats and broiler chickens after the administration of 8-OH-DPAT. In addition, hypophagic response induced by $8-\mathrm{OH}-\mathrm{DPAT}$ in food-deprived rats was imputed to serotonin syndrome. According to Samanin et al. (1987), 8-OH-DPAT possibly acts 


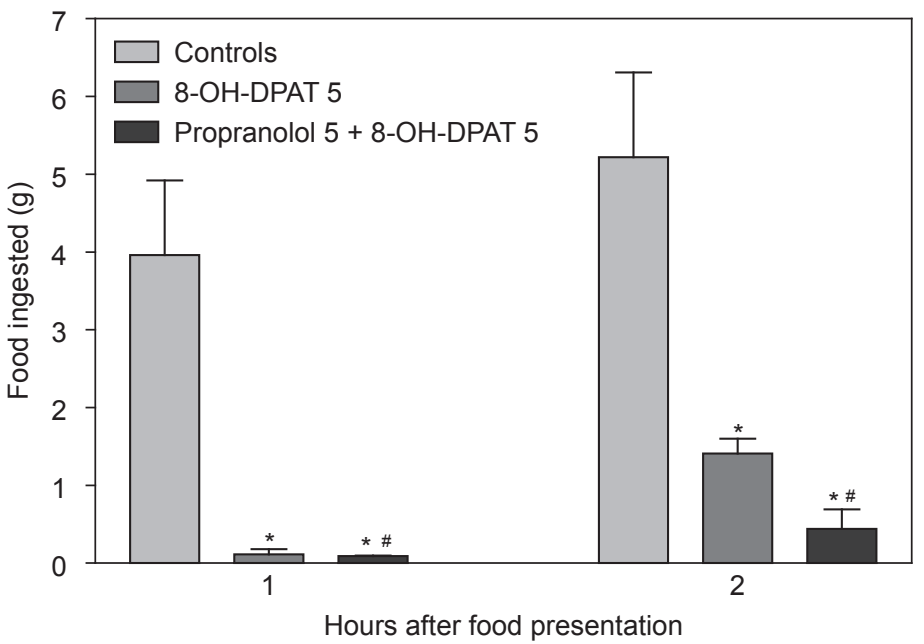

Fig. 3 - Effect of previous administration of 5-HT1A/ $\beta$-adrenergic antagonist, propranolol $(5.0 \mathrm{mg} / \mathrm{Kg}$, sc) on the food intake in normally-fed quails treated with $8-\mathrm{OH}-\mathrm{DPAT}(5.0 \mathrm{mg} / \mathrm{Kg}, \mathrm{sc})$. Data are reported as mean $\pm \mathrm{SEM}$. $* \mathrm{P}<0.01$ compared to controls. ${ }^{*} \mathrm{P}<0.01$ compared to $8-\mathrm{OH}$-DPAT alone.

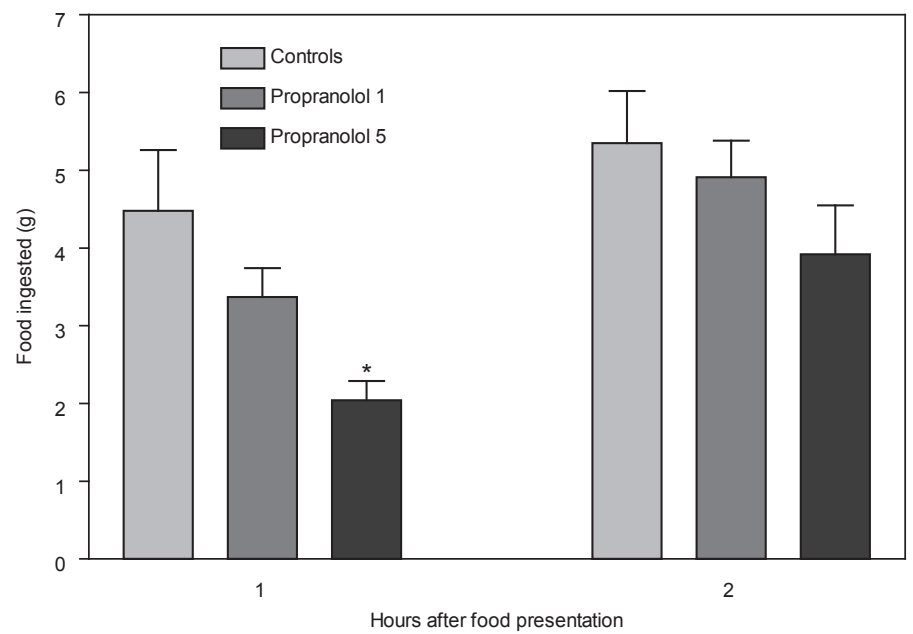

Fig. 4 - Effect of isolated administration of 5-HT1A/ $\beta$-adrenergic antagonist, propranolol $(5.0 \mathrm{mg} / \mathrm{Kg}, \mathrm{sc})$ on the food intake in normally-fed quails. Data are reported as mean \pm SEM. $* \mathrm{P}<0.01$ compared to controls.

more post-synaptically in fasted rats, resulting in a stronger serotonin syndrome (Voigt et al., 2000). This condition includes alterations in body posture and locomotion and possibly also interferes with feeding behavior in rats (Voigt et al., 2000). In this respect, our observations diverge from those of Voigt et al. (2000), because our quails presented no motor alterations that could justify the hypophagic response.

The contradictory results of our study on normally fed quails compared with those of freely fed rats raise the following hypotheses: 1) Somatodendritic autoreceptors represent distinct proteins in mammals, which do not recognize the ligand, namely 8-OH-DPAT. In other words, the ascending serotonergic transmission is dependent on a receptor subtype having a binding property unlike that of mammals. 2) The brain of quails contains a binding site for 8-OH-DPAT, possibly postsynaptic and probably distinct from those found in mammals, which are known to be 5-HT2C and 5-HT1B/ID subtypes (Blundell, 
1984, 1991; Blundell \& Hill, 1987; Curzon, 1990, 1991). In mammals, propranolol administration induces a counteraction of the hyperphagy elicited by activation of midbrain 5-HT1A autoreceptors. However, the response in quails was the opposite of that described for mammals, i.e., surprisingly, the administration of propranolol intensified the hypophagy induced by $8-\mathrm{OH}-\mathrm{DPAT}$. The isolated administration of a higher dose of propranolol also induced a hypophagic response, but only in the first hour after food was offered. These results appear to suggest that propranolol blocks an excitatory mechanism mediated by $\beta$-adrenergic activity. Two brain adrenergic mechanisms are involved in the control of food intake in mammals. The first is excitatory, mediated by $\alpha$-adrenergic activation, while the second, inhibitory, is mediated by $\beta$-adrenergic stimulation (Bray, 1985). The excitatory $\alpha$-adrenergic mechanism has been demonstrated in birds, particularly in chickens (Gallus domesticus) (Bungo et al., 2002). Therefore, the opposite condition presumably occurs in quails, in which the $\beta$-adrenergic mechanism is assumed to be excitatory.

Studies are ongoing to characterize the nature of the inhibitory actions of 8-OH-DPAT and propranolol on the feeding behavior of quails.

Acknowledgments - The authors thank FAPERJ (Brazil) for its financial support of this work.

\section{REFERENCES}

AGHAJANIAN, G. K., SPROUSE, J. S., SHELDON, P. \& RASMUSSEN, K., 1990, Neuropharmacology of serotonin: Electrophysiology of the central serotonin system. Receptor subtypes and transducer mechanisms. Ann. N. Y. Acad. Sci., 600: 93-103.

AZMITIA, E. C. \& SEGAL, M., 1978, An autoradiographic analysis of the differential ascending projections of the dorsal and median raphe nuclei in the rat. J. Comp. Neurol., 179: 641-668.

AZMITIA, E. C., 1987, The CNS serotonergic system: progression toward a collaborative organization, pp. 61-73. In: MELTZER, H. Y. (ed), Psychopharmacology: Third Generation of Progress, Raven Press, New York.

BENDOTTI, C \& SAMANIN, R., 1986, 8-Hydroxy-2(di-n-propylamino) tetralin (8-OH-DPAT) elicits eating in free-feeding rats by acting on central serotonin neurons. Eur. J. Pharmacol., 121: 147-150.

BENDOTTI, C \& SAMANIN, R., 1987, The role of putative 5-HT1A and 5-HT1B receptors in the control of feeding in rats. Life Sci., 41: 635-642.
BLUNDELL, J. E., 1984, Serotonin and appetite. Neuropharmacology, 23: 1537-1551.

BLUNDELL, J. E., 1991, Pharmacological approaches to appetite suppression. TIPS, 12: 147-157.

BLUNDELL, J. E. \& HILL, A. J., 1987, Nutrition, serotonin and appetite: Case study in the evaluation of a scientific idea. Appetite, 8: 183-194.

BRAY, G. A., 1985, Autonomic and endocrine factors in the regulation of food intake. Brain Res. Bull., 14: 505-510.

BUNGO, T., HIGAKI, T., UEDA, H., \& FURUSE, M., 2002, Intracerebroventricular administration of octopamine stimulates food intake of chicks through alpha (2)-adrenoceptor. Physiol. Behav., 76: 575-578.

CEDRAZ-MERCEZ, P. L., ALMEIDA, A. C., COSTA-ESOUSA, R. H., BADAUÊ-PASSOS JR., D., CASTILHOS, L. R., OLIVARES, E. L., MARINHO JR., A., MEDEIROS, M. A. \& REIS, L.C., 2003, Influence of serotonergic transmission and postsynaptic 5-HT2C action on the feeding behavior in Coturnix japonica (Galliformes: Aves). Braz. J. Biol. (submitted)

CHALLET, E., MICELI, D., PIERRE J., REPERANT, J., MASICOTTE, G., HERBIN, M. \& VESSELKIN, N. P., 1996, Distribution of serotonin-immunoreactivity in the brain of the pigeon (Columba livia). Anat. Embryol. (Berl), 193: 209-227.

COZZI, B., VIGLIETTI-PANZICA, C., ASTE, N. \& PANZICA, G. C., 1991, The serotoninergic system in the brain of the Japanese quail. An immunohistochemical study. Cell Tissue Res., 263: 271-284.

CURZON, G., 1990, Serotonin and Apetite: Neuropharmacology of serotonin. Ann. N. Y. Acad. Sci., 600: 521-531.

CURZON, G., 1991, Effects of tryptophan and of 5-hydroxytryptamine receptor subtype agonists on feeding. Adv. Exp. Med. Biol., 294: 377-388.

DOURISH, C. T., HUTSON, P. H., KENNETT, G. A. \& CURZON, G., 1986, 8-OH-DPAT induced hyperphagia: Its neural basis and possible therapeutic relevance. Appetite, 7 (Suppl): 127-140.

DUBÉ, L. \& PARENT, A., 1981, The monoamine containing neurons in avian brain: I. A study of the brain stem of the chicken (Gallus domesticus) by means of fluorescence and acetylcholinesterase histochemistry. J. Comp. Neurol., 196: 695-708.

DUCHALA C. S., OTTINGER M. A. \& RUSSEK E., 1984, The developmental distribution of monoamines in the brain of male Japanese quail (Coturnix japonica). Poult. Sci., 63: 1052-1060.

FERNSTROM, J. D. \& WURTMAN, R. J., 1971a, Brain serotonin, content: Increase following ingestion of carbohydrate diet. Science, 174: 1023-1025.

FERNSTROM, J. D. \& WURTMAN, R. J., 1971b, Brain serotonin content: Physiological dependence on plasma tryptophan levels. Science, 73: 149-152.

FERNSTROM, J. D., 1983, Role of precursor availability in control of monoamine biosynthesis in brain. Physiol. Rev., 63: 484-546. 
GLEESON, S., WEISSMAN B. A., SEGGEL M. R. \& BARRET J. E., 1992, Neurochemical effects of 5-HT1 receptor ligands in pigeons. Eur. J. Pharmacol., 229: 109-115.

GRUSS, M. \& BRAUN K., 1997, Distinct activation of monoaminergic pathway in chick brain in relation to auditory imprinting and stressful situations: a microdyalisis study. Neuroscience, 76: 891-899.

HUTSON, P. H., DOURISH, C. T. \& CURZON, G., 1986, Neurochemical and behavioral evidence for mediation of the hyperphagic action of 8-OH-DPAT by 5-HT cell body autoreceptors. Eur. J. Pharmacol., 129: 347-352.

HUTSON, P. H., DOURISH, C. T. \& CURZON, G., 1988, Evidence that the hyperphagic response to 8-OH-DPAT is mediated by 5-HT1A receptors. Eur. J. Pharmacol., 150: 361-3366.

PARENT, A., 1981, Comparative anatomy of serotoninergic systems. J. Physiol. (Paris), 77: 147-156.

PARENT, A., DESCARRIES, L. \& BEAUDET, A., 1981, Organization of ascending serotonin systems in the adult rat brain. A radioautographic study after intraventricular administration of $\left[{ }^{3} \mathrm{H}\right] 5$-hydroxytryptamine. Neuroscience, 6: 115-138.

REIS, L. C., ALMEIDA, A. C., CEDRAZ-MERCEZ, P. L., OLIVARES, E. L., MARINHO JR, A., THOMAZ, C. M,
2005, Evidence of the participation of serotonergic system in the control of feeding behavior in Coturnix japonica (Galliformes: Aves). Braz. J. Biol. 65(2): 353-361.

ROSEBROUGH, R. W., 1996, Crude protein and supplemental dietary tryptophan effects on growth and tissue neurotransmitter levels in the broiler chicken. Brit. J. Nut., 76: 87-96.

SAADOUN, A. \& CABRERA M. C., 2002, Effect of the 5-HT1A receptor agonist 8-OH-DPAT on food and water intake in chickens. Physiol. Behav., 75: 271-275.

SAKO, H., KOJIMA, T., \& OKADO, N., 1986, Immunohistochemical study on the development of serotoninergic neurons in the chick: I. Distribution of cell bodies and fibers in the brain. J. Comp. Neurol., 253: 61-78.

SHIMIZU, N., TAKE, S., HORI, T. \& OOMURA, Y., 1992, In vivo measurement of hypothalamic serotonin release by intracerebral microdyalisis: Significant enhancement by immobilization stress in rats. Brain Res. Bull., 28: 727-734.

VOIGT, J. P., KIENZLE, F., SOHR, R., REX, A. \& FINK, H., 2000, Feeding and 8-OH-DPAT-related release of serotonin in the rat lateral hypothalamus. Pharmacol. Biochem. Behav., 65: 183-189. 